\title{
身体平得機能の計测・分析技術に閶する研究 水平加速外乱を用いた新型の立位姿勢評価試検機
}

\author{
永田久雄 （労傎省産業安全研究所）
}

大野央人（铁道総合技術研究所）

Study on measurements and analysis of human equilibrium

- New device for evaluating human standing posture against horizontally accelerated disturbance

Hisao NAGATA (National Institute of Industrial Safety)

Hisato OHNO (Railway Technical Research Institute)

\section{1.はじめに}

レール上の走行台（長さ $11 \mathrm{~m}$ 、有効可動距離 9. 2m）をサーボモーターの駆動力で急加速さ せる装置"（リニアアクセラレー夕）により、被験者に 急加速負荷刺激を与えて、立位姿勢の安定性 を評価することができることを報告した ${ }^{2)}$ 。 しかし、レールが長いために大型の実験室を 必要とする。その欠点を補うために、走行長 さを短くした小型の試験機を開発した。本機 を用いた基本的な測定法について検討を行っ たので概要を報告する。

\section{2. 開発した立位姿势安定性評価試唤機}

\section{(1) 基本}

立位姿勢に矩形波状の加速力を与えた時に、 姿勢を保持できる限界の加速度とその加速時 間との関係を検証してきた 2$)$ など。その結果、 立位バランスを失わせる限界加速度は加速時 間の逆数值に比例することを確証した。直線 的な関係から、ある二点の特性が定まれば全 体の傾向がつかめることになる。つまり、数 少ない測定によって種々の立位条件別の身体 特性を解明することができる。本機はこの理 論を基本としているが、直線性を再検証する ために本報では二点以上の加速時間について も限界加速度を測定している。

(2) 新試験機の機構など

図 1 に示した新試験機のレール長は $2 \mathrm{~m}$ （有 効可動距離 $1.0 \mathrm{~m})$ である。走行台のレール長 によってサイズを比較すると大型装置の約 $1 / 5$ である。新たな試験機の加速法は従来の大型 の装置（リニアア切ラレータ）と同様に被験者が立っ ている走行台をスライドさせて，立位姿勢に 加速外乱を与える方法である。

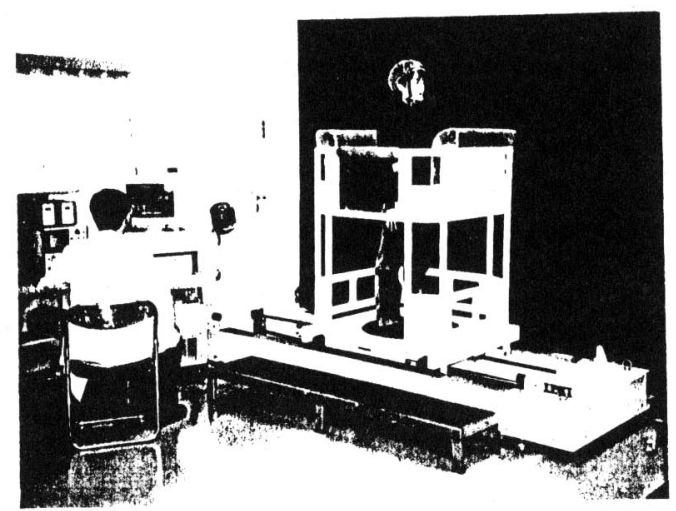

因 1 立位姿勢安定性評価武験機

本体構成は, 駆動部, 走行部, パソコン制 御部, 水晶式加速度検出部、レーザー光式速 度計からなる。駆動部は位置制御型のサーボ モータシステムを採用している。位置検出セ ンサーはタコジェネレータとポテンションメ 一タを用いている。

本装固はサーボモータをパソコン制御する 方式のため、正弦波、三角波などの刺激を作 り出すことが可能である。しかし、ここでは、 突発的な立ち上がり刺激である矩形波状の加 速力についてのみ論じている。

\section{3. 実跧}

被験者は男子で、2グループに分けて実施し た。

(1) 加速後から減速までの時間別の特性

本機の走行台の移動距離が短いため、加速 後の走行時間を長く取れない。加速後から減 速までの一定速度走行の持続時間が長ければ 長いほど減速ブレーキによる摇れ戻しは生じ にくい。この影響を取り除くために必要な最 
小時間を求める実験を行った。

実験では、0，200，400，700，1000,1500ms の6段階をとり、姿勢を保持できる限界值をそ れぞれ求めた。加速時間は約 $100 〜 1200 \mathrm{~ms}$ の範 囲内の5点を取っている。被験者は，男子7名 で平均年齡22.7歳（19～26歳）である。平均身 長は175. 2cmである。その結果を図 2 に示した。 結果から、いずれの場合でも直線性が見られ 加速後から減速するまでの一定走行時間を少 なくとも $1000 \mathrm{~ms}$ 以上取る必要があることが判 明した。

\section{(2) 開眼之遮眼別の特性}

視覚情報が立位バランスに大きな影警を及 ぼすことは知られている。そこで、開眼と遮 眼（アイマスク使用）による立位限界への影 響を調べた。加速後から減速するまでの時間 は1500msである。加速時間は約125～1000msの 範囲内の 5 点を取っている。被験者は, 前項と は別グループの男子6名である。平均年齢23.5 歳(20～29歳)、平均身長は, $169.1 \mathrm{~cm}$ である。 その結果、図 3 に示すように直線的な関係が 見られかつ、矩形波状の加速刺激では開眼遮 眼による差がほとんどないことが判明した。

\section{（3）前傾姿勢と後傾姿勢別の特性}

自然体、大きく前傾、後傾させた状態につ いてその立位保持特性の差を求めた。加速時 間は約1 25〜 1000msの範囲内の5点を取ってい る。前項の被験者 6名を用いて実測した。そ の結果、図 4 に示すように、直線性が見られ かつ、前傾姿勢と後傾姿勢で大きな差が生じ ることが判明した。

\section{4. まとめ}

男子若年齢者による実験では、加速後に減 速するまでの一定速度走行時間を少なくとも $1000 \mathrm{~ms}$ 以上取る必要がある。

矩形波状の刺激の場合には閉眼、遮眼によ る影響はほとんど見られないが、大きく前傾 あるいは後傾した場合には、その姿勢差が大 きく現れる。

本機を更に改良し主に労働安全の分野で問 題となっている課題について応用する予定で あるが、本機の特性に配慮することにより、 乗り物の研究、平衡メカニズムの解明、リハ ビリの効果、立位機能全体の反射特性、予告 ・構えの効果などの研究に幅広い応用が可能 であろう。

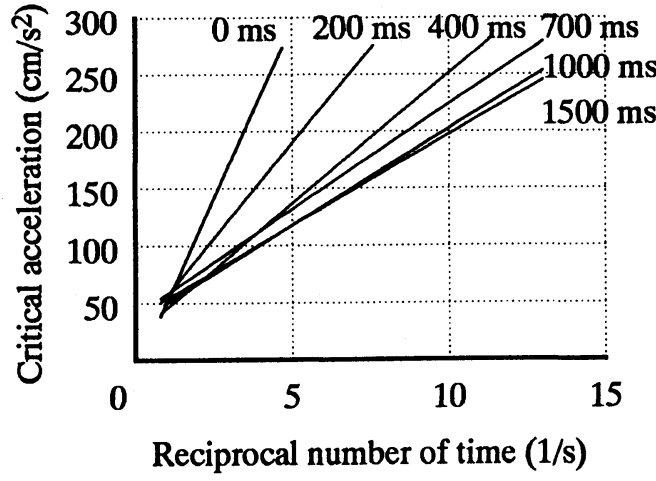

図 2 一定速度走行の持続時間別特性

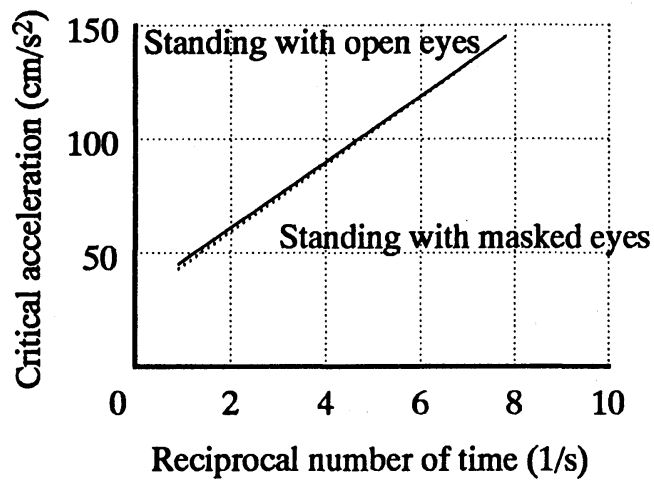

図 3 開眼遮眼別の特性

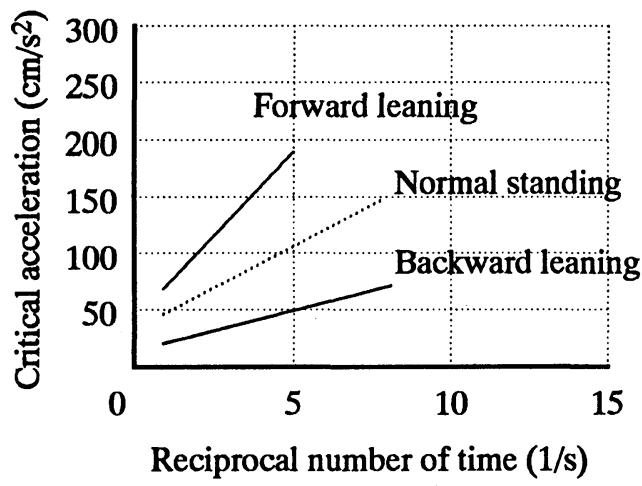

図4 前傾と後傾別の特性

\section{参孝文献}

1）永田久雄 : 急加速刺激を加えた場合の立位姿勢の 安定性評価装圈の開発, 人間工学, $27(4), 221-223$, 1991.

2）永田久雄, 大野央人, 小美浱幸司:水平加速外力に対 する靴ヒール高別の立位姿勢の保持限界に関する 